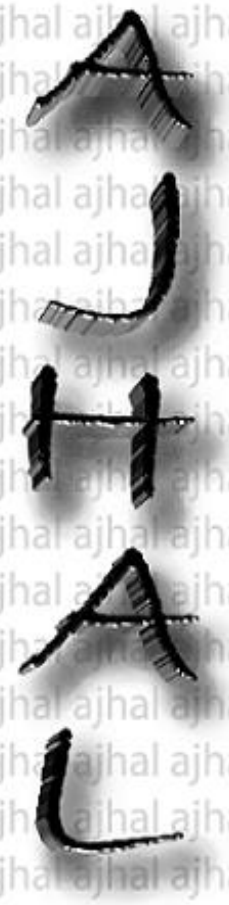

[SSN 23141-8636

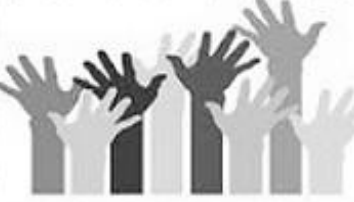

THERET5חQ E与口月P工凡丶

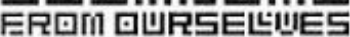
Tㅏㅌㅡ HШाாП

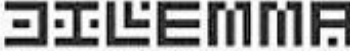
IS AS ITI HAS คกㅋ 트 5ㅁㄴㅃㅌㅡ

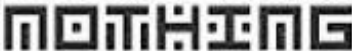
ЕயாコคMEாாாคடட

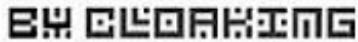
口யR5Eடᄂ凹ㄷ

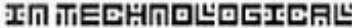
ए Vol 3, No. 2/2016

Asian Journal of Humanity, Art and Liteleatulu'e

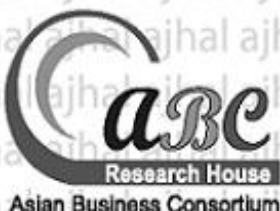




\title{
Cognitive Learning Strategies and the Students in Tertiary Institution
}

\section{Janet Ngozi Igbo $^{1 *}$, Mbagwu Felicia ${ }^{2}$, A. Oboegbulem ${ }^{3}$}

ISSN: 2311-8636 (Print)

ISSN: 2312-2021 (Online)

DOI prefix: 10.18034/ajhal

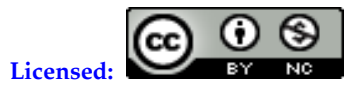

Source of Support: Nil

Conflict of Interest: None Declared

*Email for correspondence:

ianotichnfmrahon rom

\author{
${ }^{1}$ Department of Educational Foundations, University of Nigeria, \\ Nsukka, NIGERIA \\ ${ }^{2}$ Associate Professor, Department of Adult Education, University of \\ Nigeria, Nsukka, NIGERIA \\ ${ }^{3}$ Associate Professor, Department of Educational Foundations, \\ University of Nigeria, Nsukka, NIGERIA
}

\section{ABSTRACT}

The level of students educational performances remain sources of concern to every stakeholder in the education sector. Many techniques have been tried to find the solution to this problem. Researchers have recommended different methods more especially cognitive learning strategies. Recently, students have been exposed to cognitive learning strategies, yet the performances of students do not justify the application of these strategies. The researchers examined the extent of students' awareness of these cognitive strategies as well as the extent of the application. The study was guided by two purposes and two research questions. The study adopted the descriptive survey design. In carrying out the study Faculty of education, University of Nigeria was used. The results indicated that the students are aware of almost all the cognitive strategies, but the problem was that the students minimally applied these learning strategies. While some were not applied at all.

Key Words: Learning, application, cognitive learning strategies, awareness

\section{INTRODUCTION}

Learning is a change in behavior, which can manifest overtly or covertly depending on the situation. Learning has to do with the individual's day-to-day experiences. According to Ramalingam (2006) learning is a relatively permanent modification of behaviors that results from experiences or practices. Through learning individuals gain or acquire experiences, knowledge, capabilities and skills. For Saljo, (1991) and Hartly (1998), learning is conceptualized or defined in five ways: as a means of acquiring knowledge; storing and remembering information that could be used later. It is the acquisition of facts, knowledge and method; abstracting meaning from materials; and process that assists the interpretation of understanding of reality. The implication is that learning has to do with acquisition of knowledge and clarification of the acquired knowledge for meaningful application of these experiences.

Usually, students are influenced by the acquisition of knowledge gained from their instructors, which mostly come with verbal descriptions of different constructs. The students' daily activities involve rules and regulations applicable in the process of 
teaching. The worrying situation is that the outcome of these teaching strategies can be upsetting and needs to be addressed. To save the situation before it gets out of hand. For instance, presently, in the Nigerian university system most students find it difficult to think or learn beyond what the lecturers had taught them. Very often, students are seen to be more or less passive than active in the lecture halls. In the same view Edge (2007) stated that teachers act as store of knowledge and power that pass information through teaching while possessing absolute control of the entire classroom. The students lack of cognitive learning strategies might have made it difficult for them to graduate from the University, as when due. Recently, the Government Council of the University of Nigeria granted the Vice Chancellor's request through the Senate for an extra one year for students who had over-stayed in the university to graduate. Student who cannot afford to graduate will be expelled. In agreement with the above statement, the American Association for the Advancement of Science (1996, 2005), National Council for the Social Studies, $(2002,2006)$, National Council of Teachers of English, $(1996,2006)$ and the National Council of Teachers of Mathematics $(2002,2006)$ in their studies found many students unable to think independently of the teacher or to go beyond the content of their texts and workbooks. Going by this assertion is in the developed countries where teaching and learning facilities are easily available; one can imagine the Nigerian situation where some lectures are held in the school stadium, corridors, and in open spaces due to lack of enough lecture halls, public address system for large classes and other critical infrastructures.

Most of the lectures appear to be teacher-centered instead of being students centered. As a result, students are more interested in acquiring every knowledge related to a particular course from the lecturers without making any effort to apply own knowledge. Rather than focusing on activities that will enable them acquire facts, rules and principles involved in the process of learning, students tend to be passive, to rely basically on information gathered from the lecturers and their knowledge. The situation has become so appalling that it needs to be addressed. In the researchers' opinion, cognitive learning strategies might have the solution to this problem that is facing our tertiary institutions. The researchers observed that the present curricula are isolated by disciplines that merely identify lists of topics, facts, and skills to be covered by the end of each semester. These curriculums mainly put the learners in a relatively passive role and encourage rote or other forms of inactive learning (Borich, 2011). The issue involved, in this case, is that lecturers tend to concentrate more on covering the already stated topics rather than emphasizing on what the students will achieve. Posamentier and Krulik (2008) and Viadero (2003) Cognitive learning strategies emphasize on organizing on real-life problems based on daily activities. Learning may be more meaningful if the application of reallife situations is involved. This type of integrative learning is absent in most standards-based curriculum. The fact is that the substance of the curriculum has usually been legislated as a package to different schools. (Wiles and Bondi, 2011). These facts led the researchers' intention to ascertain the perception of lecturers on the level of knowledge and the frequency of the application of these cognitive strategies in the university system.

Cognitive learning strategies are seen as higher order thinking skills and problem- solving techniques. These involved the application of mental strategies that students apply in the process of learning. Borich (2011) sees cognitive strategies as general method of thinking that improves learning across a variety of subject areas. Cognitive strategies give students the opportunity to achieve higher-order outcomes that are required in the process of learning, more especially in tertiary institutions. In cognitive strategy, individuals use mental abilities to enable them to learn on their own. It involves general method of thinking that improves learning across a variety of subject area (Borich, 2011). These strategies are more complex and less teacher centered. These strategies bring students 
concepts and experiences into the topic under study and enable the students to evaluate their responses. These strategies improve positive student's attitudes towards learning in the classroom situations (Williams, 2003, Broich and Jombari, 2004, Tombari and Borich, 1999). This implies that in cognitive strategies students' ideas, self-evaluation and classroom dialog are emphasized and encouraged by the lecturers. Blanton (2005), states that cognitive learning strategies make learning to be easier by helping the students to retain in-coming information (reception), recall knowledge acquired and build logical connections in the in learned materials (Borich and Tombari, 2004). These involved the adaptabilities of encoding information appropriately with the combination of experiences already acquired. Borich (2011) identified some cognitive strategies such as self-directed learning, functional errors, reciprocal teaching social dialog versus class discussion and the role of inner speech. Other cognitive strategies include memories (memory aids), elaboration, problem-solving, and project-based. Cognitive strategies link new information to prior knowledge, restructuring students background knowledge, teaching them how to learn, establishing motivation toward a stated goal and at the same time teaching students how to apply existing knowledge to learn more (wiles and Bondi, 2011). Therefore, cognitive strategies are seen as integrative learning.

Basically, organization of experiences or knowledge is a skill that aids students' success in learning, and this is one aspect of cognitive strategies that needs to be encouraged by the teacher. The demand for these new strategies which will bring accountability for learning is required as the teaching force in schools (Tye and O'Brien, 2002). In this particular paper the researchers intend to concentrate on the following cognitive teaching strategies: reciprocal teaching strategies, comprehension strategies, problem-solving strategies, project-based, project-based, self- regulation, reasoning and mnemonic strategies.

Project- based type of learning provides enabling the environment that is appropriate for students to learn. According to Borich (2011) the teacher communicate with the learners the importance of learning process, and help them to set objectives Project-based strategy makes use of intrinsic motivation strategy (Affin, 1996, Chinn, and Brewer, 2001). In this learning strategy the interest of the teacher is basically on an achievable outcome through intrinsic motivation. It encourages and energizes classroom activities, keeping the students active rather than passive. Project- based strategy require several weeks completion of the project, it involves small group assignment while the teacher acts as the moderator (Diffily \& Sassman, 2002, Harada, Kirio, Yamamoto, 2008 \& Borich, 2011). In this type of situation no learner is supposed to be passive.

Self- regulation strategies: Self- regulatory strategies are those strategies that encourage learners to control their learning process without the supervision of others. These are cognitive strategies that encourage learners to set objectives for themselves and target their objectives to enable them to achieve the stated objectives. Learners tend to choose patterns of studying to enable them to get to their objectives. Sometime, they monitor their strength and weaknesses and areas that require attention. Self regulation involves the purposeful functioning of individuals with different levels of organization and complexity. It equally involved mental self- regulation with individual activities that reflect the reality of the person. Self- regulation strategies involves how students organize themselves and interpret acquired information. It involves organizing, setting goals, transforming information, time management, and monitoring self. Therefore in self- regulation strategies lecturers basically encourage students in keeping records, monitoring, organizing, hearing information they must have acquired in the process of learning.

Comprehension strategies: These are the strategies that enable students to understand and remember materials that were thought, such as tests and lecture. For Chinn (2006) learning are 
basically acquired from texts. According to Guthrie et al (2004) and Langer (2001) to five strategies were found to enhance learning while applying comprehension strategies. These include monitoring using test structure, summarizing, elaborating and explaining. It involves the process of students mentoring their progress in learning, they tend to make some appropriate adjustment. At time, there might be some misconception of understanding because some students might claim that they know it all. According to Keirns (1998) when student monitors the understanding of materials by reviewing what they had learned the students need to apply structure to enhance acquire comprehension. This requires the application of individual cognition because it involves the organization of concepts which involves things like underlining, highlighting, giving headings on particular issues under study. Beyer, (1995) noted that these cues are used by proficient students to enable them to organize ideas together for easy understanding. Summarizing is required in comprehension strategies because it enable the students to outline the key points and pull them together for easy reading and understanding. According to Hester, (1994) summarizing involves the ability of the students choosing the most important concepts from a test and putting or expressing the ideas together in their own words. The researcher observed that presently most students are unable to summarize texts may be due to their poor learning strategies. For Edge (2007) elaboration is the ability to link actively the new information or experience to already learned or old information. From all indication, the application of this strategy requires proper cognition in the process of learning and teaching. Chuska (2003) noted that comprehension strategy is a process whereby students learn to evaluate their personal understanding by frequently checking their progress during learning.

The reciprocal strategy is a cognitive teaching strategy that gives opportunities to explore the content to be learned through classroom dialog. It involves group discussions in which the lecturers and students take turns as group leaders in discussing a particular topic or text (Borich, 2011, Lubliner, and Palincsat, 2011 and Oczkus, 2005). The implication is that students are considered in the process of teaching to enable the lecturer find out the gaps that required to be filled up in the process of teaching and learning. It is a cognitive strategy that gives equal than the recitation of facts by students (Chuska, 2003 and Slavin, 1990, 2001). Reciprocal strategy is a technique that turns a typical discussion into a more productive and self-directed learning experience. It is acquired through predicting, questioning, summarizing and clarifying (Oczkus, 2005, Palincsar and Brown 1989). This strategy encourages self-expression that is required in higher order learning applicable in tertiary institutions. Mutual interaction between the lecturers/teachers and students is most desirable in this type of teaching and learning environment. In the application of reciprocal teaching strategies, the student can apply comprehension and monitoring patterns of learning. The students participate fully in reciprocal strategy in the process of learning that makes learning more interesting.

Mnemonics - This is a learning strategy that helps students to retain learned information. It is processes that enable learners to acquire information in a short form for better understanding of the construct. It is a process of compressing information to me memorized for easy retrieval. According to Mangal, (2009) mnemonics is a device that helps individuals to remember, improve and develop information in the memory. It usually applies visual imagery to enhance useful association for remembering needed materials. For Martin, Carlson and Buskist (2007) mnemonic is a special technique consciously applied to improve memory by making use easier memorization of acquired information. The implication is that students need to be active in the process of learning for appropriate coding and storing of information in the long-term memory. Storing information in the long-term memory requires a lot of motivational strategies. 


\section{Review of Related Studies}

In a study carried out by Norton and Crowley (1995) on the effect of incorporating workshops into a first year psychology course on students' learning strategies. The performance of students who attended the workshops regularly were compared with those who attended once, twice and those who did not attend. The results indicated the increase in deep processing with the students who attended regularly. They adopted deep learning processing style as the course progressed while the other group was operating with a shallow learning process. This study is in line with the present study on cognitive teaching and learning that encourage students to think, interpret and to have the personal perception on concepts and ideas. In a related study by Martin Carlson, and Buskist (2007) on summarizing articles. A group of students that were classified into shallow and deep learners were given an article with 1400-words and were asked to summarize it in two sentences. The students placed as shallow learners were unable to summarize the article, but the students placed as deep learners found it easy to summarize. The indication is that when students learn on the basis of trying to concentrate or remembering concepts and ideas, pulling ideas together become a problem. On the other hand, it also indicated that when students learn with efforts to get the principal idea, learning becomes part of the students. Therefore, in the process of teaching, applying cognitive strategies that encourage understanding of points and ideas and making use of them based on the individual perception the stress that goes with teaching and learning becomes less.

In another study carried out by Chamberlian (1998) on the importance of dialogue between the teacher and the students in the process of teaching and learning. The findings indicated that lack of dialog projects a serious problems the students as passive rather than active them. When cognitive strategies are applied this might make learning easier for the students. Students and teachers make teaching and learning to flow.

In similar studies carried out by Beyer (1995), Borich and Tombari (2004) and Hester (1994) on students higher order thinking and problem solving. The results indicated that many students are unable to think or to solve problems beyond the content given to them by their teachers. The findings equally showed that the manner in which most schooling occur do not teach students to be aware of the learning process or to think critically. The results also indicated that students lack patterns of thinking about cognitive learning strategies. From all indications, it seems that learning has been undervalued probably because students are not encouraged as required. For learning to yield more effective result, it needs to change its dimension to accommodate students' diversity. Focusing on the cognitive learning strategies that emphasize more on students' active participation in the process of learning, might have the solution to this problem. The authors emphasized that for learning to be improved course designers should take account of outcome-based and students approaches to learning. It is based on this that the researchers carried out this study to ascertain the levels of awareness of cognitive learning strategies and the extent of the application by students in the process of learning. Specifically, the study emphasized on two major purposes and research questions.

- To examine the students' perception on their level of awareness on some identified cognitive learning strategies in the tertiary institution.

- To find out the level of the frequency of the application of the cognitive learning strategies.

Research Questions

- What is the students' perception of their level of awareness on cognitive learning strategies?

- What is the student perception on the frequency of appling these cognitive learning strategies? 


\section{ReseARCh Method}

The researchers adopted the descriptive survey design. The reason for choosing descriptive survey design is in line with Punch (2011) ascertain that it involves drawing a picture of how events are like. Again, it's purpose is mainly to describe some samples in terms of simple proportions and percentages of people whose views are different according to the questions raised. Besides, it also involves a systematic approach of research studies. The study was carried out in the Faculty of education University of Nigeria, in Enugu state of Nigeria. The faculty has seven departments: adult education, art education, educational foundations, health and physical education, library science education, science education and the department of vocational and teacher education. The choice of this study area is the availability of the students who are attending classes in the process of learning. The population of the study consists of all the final year students in the faculty of education university of Nigeria. Available statistics show that there are 210 final year students from Vocational Teacher Education and Educational Foundations Departments in the Faculty of Education. The researchers adopted multi-stage sample technique. First, proportionate sampling was applied to select University of Nigeria. This was basically, because it is situated at the center of the south east of Nigeria. Secondly, purposive sampling technique was used in selecting students from the two departments instead of the entire Faculty of Education in the University. Students found in the Faculty are from all parts of the country and outside the country.

The instrument was validated by three experts, in psychology and educational psychology, from the faculty of social sciences and faculty of Education, University of Nigeria, Nsukka.The researchers Some expunged the inappropriate items while the appropriate ones were retained. To determine the reliability of the instruments, a trial test was administered out by giving the data to students in Imo state university that is entirely outside the study area. This is to determine the internal consistency of the instrument. Cronbach statistical analysis was used on the data collected, and the result showed the alpha co-efficient value of 0.82 and 0.87 for the sections of awareness and application of these cognitive strategies respectively. Results gathered indicated that the instrument was reliable. The total numbers of 210 students was used for the study. There was no sampling of the subjects. The basis for using the entire subject is because the number is handy and manageable. The more the number, the more reliable the results from the study will be. The basis for using only the final year students is the understanding that they had stayed in the university for years and are practically involved in the learning processes. On the extent of the usage of these cognitive learning strategies. The format for responses was ranged as follows: Fully aware, partially aware, and not aware for the first section that has to do with the level of awareness. The second section was ranged as: Always, often, sometimes and Never. This segment has to do with the usage of the cognitive learning strategies. The researchers distributed 210 copies of the questionnaire to the respondents. On the spot, collection was made .The researchers acquired $100 \%$ return. The data was analyzed using percentage.

\section{Result And Discussion}

Table 1: Students' view on their range of knowledge of Cognitive Strategies

\begin{tabular}{llccc}
\hline S/N & Cognitive Learning Strategies & Fully Aware & Partially Aware & Not aware \\
\hline 1 & Self-regulatory & 101 & 2 & - \\
2 & Mnemonics & 03 & 07 & 02 \\
3 & Reciprocal & 09 & 10 & 01 \\
4 & Comprehension & 13 & 07 & 02 \\
5 & Project based & 49 & 04 & - \\
& Total/ percentage & 175 & 30 & 05 \\
& & $(83.33 \%)$ & $(14.29 \%)$ & $(2.38 \%)$ \\
\hline
\end{tabular}


The data presented on Table 1 indicated that $83.33 \%$ of the students in the university were of the opinion that they are fully aware of self-regulatory, mnemonics, reciprocal, comprehension and project strategies. On the other hand, $14.29 \%$ and $2.38 \%$ recorded partial and lack of awareness respectively.

Table 2: lecturers' view on their level of application of cognitive learning strategies

\begin{tabular}{llcccc}
\hline S/N & Cognitive Learning Strategies & Always & Sometimes & Rarely & Never \\
\hline 1 & Self regulatory & 29 & 27 & 11 & 03 \\
2 & Mnemonics & 08 & 02 & 03 & 08 \\
3 & Reciprocal & 18 & 12 & 12 & 01 \\
4 & Comprehension & 25 & 07 & 08 & 02 \\
5 & Project based & 11 & 16 & 09 & 03 \\
& Total/ percentage & 86 & 64. & 43 & 17 \\
& & $(40.95)$ & $(30.48 \%)$ & $(20.48 \%)$ & $(8.09 \%)$ \\
\hline
\end{tabular}

Data revealed on Table 2 revealed that $40.95 \%$ of the students apply a combination of cognitive strategies in learning. While $30.48 \%$ apply them sometimes, $20.48 \%$ and $8.09 \%$ use these strategies rarely and never respectively.

\section{Discussion OF THE RESULTS}

Going by the result of the study, $57.78 \%$ of the students accepted that they have the complete knowledge of, self- regulatory strategy, reciprocal, comprehensive strategy, project-based, and mnemonics strategies. $31.75 \%$ have partial knowledge while $10.75 \%$ have no knowledge. The results are not encouraging because at university level all the students are supposed to be fully aware of these cognitive learning strategies for easy and active learning. From the data, the students claimed that they are completely aware of most of the cognitive learning strategies but from the researchers observed that few students apply them, while most of the students do not apply these cognitive strategies. Those who apply them do that without knowing the exact pattern or strategies that they are applying. This was as observed by the researchers in the process of carrying out the research

Actually, the interest of the students based on extrinsic motivation learning, that is to say that motive is more on passing examinations rather than what comes after learning. Therefore they regard the application of these learning strategies as a waste of time because of the time limit assigned to that particular unit before examination. This is in line with the findings of Wile and Bondi (2011) who found that standard-based curriculum among other things is more interested in the substance of the curriculum than any other aspect of the curriculum. Therefore lecturers emphasis is more on addressing the topics legally stated or outline for the year in the curriculum rather than what the students might achieve.

The results also indicated that most of the students are aware of these cognitive strategies but found no time in applying them. This is in agreement with Fafunwa (1996) who noted that the awareness and application of different teaching and learning strategies help for easy classroom management and for better achievement. The implication is that for learning to yield positive result, it needs to accommodate practical dimensions. Costa and Kallick (2003) found that for learning to be improved course designed should take proper account of outcomes-based on students-centered approaches in teaching and learning. According to Harda, Kirio and Yamamoto (2008) and Viadero (2003) urged school reforms that encourage project- based strategies which engage the students in active participation as the appropriate way to develop self-directed learning. The indication is that learners will gain relevant experiences in the process of learning through self- effort. The students will perceive 
themselves as competent learners. From the findings, it implies that the cognitive learning strategies are approaches that do not limit the students in only remembering concepts and ideas, but also emphasize on active participants in the classroom situations.

\section{CONCLUSION}

Cognitive strategies involve deep learning which emphasized on knowing and understanding materials through practical activities. It is a deliberate manipulation of concepts to enable the learners to improve learning. Cognitive learning strategies involve deep learning. The findings of the present study suggest that learning has not been altogether encouraging. There are indications that students concentrated on one or two cognitive learning strategies in acquiring academic achievement. Evidences from literatures reviewed advocate the combination of learning strategies for effective academic achievement.

\section{REFERENCES}

Affini, J. (1996). 150 ways to increase motivation in the classroom. Boston: All \& Bacon.

Ahmed AA, Siddique MN and Masum AA. 2013. Online Library Adoption in Bangladesh: An Empirical Study University of Bahrain Best Practices in Management, Design and Development of e-Courses: Standards of Excellence and Creativity. Manama: IEEE.

American Association for the Advancement of Science (1996). Benchmarks for science Literacy. Cary. NC Author.

American Association for the Advancement of Science (2005). Benchmarks for Science Library New York: Oxford University Press.

Beyer, B. (1995). Critical thinking. Bloomington, IN Phi Delta Kappa. The educational Foundation, Fastback No, 385.

Blanton, B. (2005). The application of the cognitive learning theory to instructional Design. International Journal of Instructional Media. 25, 2,171-180.

Borich, G.D. (2011). Effective teaching methods. Research-based practice ( $7^{\text {th }}$.ed) Boston Allyn and Bacon.

Broich, G.D. \& Tombari, M. (2004). Educational assessment for the elementary and middle school classroom $\left(2^{\text {nd }}\right.$. ed $)$. Upper Saddle River, NJ: Merrill/Prentice Hall.

Burke, K. (2006). Form standard to rubrics in six steps: Tools for assessing students learning K-8. Thousand Oaks, CA Crown.

Chambelian, D. (1998). ESP in the classroom: Practice and education Oxford. The British Council.

Chamber Lain, D. (1998). ESP in the Classroom: Practice and education Oxford. The British Council.

Charleswarth, R. (1996). Understand child development $\left(4^{\text {th }}\right.$ ed) Boston Delmar publisher.

Chinn, C.A. \& Brewer, W.F. (2001). Models of data: A theory of how people evaluate data cognition and instruction, 19, 323-393.

Chinn, C.A. (2006). Learning to argue. In A.M.O.' Donnell, C. Hmelosilver, \& G. Erkens (Eds). Collaborative Learning, Reasoning and Technology (pg 355-383). Mahwah, N.J.: Erlbaum.

Chuska, (2003). Improving classroom questions: A teacher's guide to increasing student motivation participation and higher-level thinking ( $2^{\text {nd }}$ ed). Bloomington, IN Phi Delta Kappa educational foundation.

Costa, A. \& Kallick, B. (2003). Assessment strategies for self-directed learning Thousand Oaks', CA: Crown.

Diffily, D.\& Sassman C. (2002). Project-based learning with young Children. Portsmouth, NH: Heinemann.

Edge, P. (2007). Teaching and learning in the language classroom. Oxford. Oxford University press.

Fafunwa, A.B. (1996). History of education in Nigeria. Ibadan: WPS Education Ltd.

Goetz, E.T, Alexander, P.A. \& Ash, M.J. (1992). Educational psychology. A Classroom Perspective. Upper Saddle River. NJ. Merrill/Prentice Hall.

Guthrie, J.T., Wigfield, A. Barbosa, P., Perencevich, K.C., Taboada, A., Davis, M.H., et al (2004). Increasing reading comprehension and engagement through concept orientated reading instruction. Journal of educational psychology, 96,403-423.

Hard, v., Kirio, C. \& Yamamoto, s. (2008). Collaborating for project-based learning in Grades 9-12. Columbus. OH: Linworth Publishing.

Hartly, J. (1998). Learning and study: A research perspective. London. Routledge.

Hester, J. (1994). Teaching for thinking. A program for school improvement through critical thinking across the curriculum. Durham, N.C. Carolina Academic press.

Hester, J. (1998). Teaching for thinking. A program for school improvement through critical thinking across the curriculum. Durham, NC. Carolina Academic Press.

Highet, G.G. (2000). The art of teaching. London: Methuen. 
Keirn, J. (1988). Design for self instruction, principles, processes and issues in developing self-directed learning. Boston: Allyn and Bacon.

Keirns, J. S., \& Palincsat, A. (2011). A practical guide to reciprocal teaching New York. McGraw-Hill.

Langer, J.A. (2001). Beating the odds' teaching middle and high school students to read and write well. American Educational Research Journal, 38, 837-880.

Lerra, M. (2014). The Dynamics and Challenges of Distance Education at Private Higher Institutions in South Ethiopia. Asian Journal Of Humanity, Art And Literature, 1(3), 137-149.

Lubliner, S., \& Palincsat, A. (2011). A practical guide to reciprocal teaching. New York McGraw-Hill.

Mangal, S. K. (2010). Advanced educational psychology (2nd. ed) New Delhi PHI Learning Private limited.

Martin, G.N., Carlson, N.R. \& Buskist, W. (2007). Psychology (3 $3^{\text {rd }}$ ed). London, Allyn and Bacon.

National Council for the social studies (2002).The National standard for social studies teachers. Sliver Springs MD. Author.

National council for the social studies (2006). National standard for social studies teacher. Silver Springs, MD. Author.

National Council of Teachers of English (2006). Guideline for the preparation of teachers of English language arts. Urbana IL. Author.

National Council of Teachers of English (1996). Standard for the English language arts. Urbana, IL Author.

National Council of Teachers of Mathematics (2002). Principles and standard for school mathematics. Reston VA: Author.

National Council of Teachers of Mathematics (2006). Illuminating NCTM's principles for school mathematics, Reston. VA: Author.

Norton, L.S. \& Crowley, C.M. (1995). Can students be helped to Learn how to Learn? An Evaluation of an Approaches to Learning Programme for First Years Students: Higher Education 29,307-328.

Oczkus, I. (2005). Reciprocal Teaching at work. Strategies for interpreting reading comprehension. Newark: DE. International Reading Association.

Palincsar, A. \& Brown A. (1989). Classroom dialogs to promote self-regulated comprehension. In J. Brophy (ed), Advances in Research on Teaching I, 35-71. Greenwich. CT. JAI. Press.

Posamentier, A. \& Krulik, S. (2008). Problem-solving strategies for efficient and elegant solutions. Grades 612. A resource for the mathematics teachers. Thousand Oaks. CA: Corwin.

Punch, K.F. (2011). Introduction to research methods in education. London SAGE publications Ltd.

Ramalingam, P. (2006). Dictionary of psychology. New Delhi Academic (India) Publishers.

Roopnarine, J.N. (1986). Mothers' and fathers behaviors towards the sex-typed toy play of their infant sons and daughters. Sex Roles, 12, 59-68.

Rusk, R.R. (2000). The doctrines of the great educator. London. The Macmillan Press Ltd.

Sadeghi, B., \& Safari, R. (2012). The Impact of Collaborative Task on the FL Vocabulary Acquisition. ABC Journal Of Advanced Research, 1(2), 8-14.

Saljo, R. (1991). Learning and learning. Higher Education, 8,443-51.

Slavin, R. (1990). Achievement effect of ability grouping in secondary schools. A Best Evidence Synthesis. Review of Educational Research 60,471-499.

Slavin, R. (2001). Cooperative learning and inter group relations. In J. Banks and C. Banks (eds) Handbook of Research on Multicultural Education. San Francisco: Jossey-Boss.

Stadler, F. (2004). Induction and deduction in the sciences. New York. Springer.

Tombari, M. \& Broich, G. (1999). Authentic assessment in the classroom. Practice and Applications, Upper Saddle River. NJ Merril/Prentice Hall.

Tsegaye, M., \& Moges, B. (2014). Roles And Challenges of Secondary School Instructional Leadership for the Achievement of Student Learning: The Case of South Gondar Administrative Zone, Amhara Region, Ethiopia. Asian Journal Of Humanity, Art And Literature, 1(1), 48-69.

Tye, B. \& O' Brien, I.(2002). Why are experienced teachers learning the profession? Phi Delta Kappan 84, 1, 4-32.

Vasta, R. \& Lightfoot Cox, B. (1993). Understanding gender difference as on the water-level problem. The role of spatial perception. Merrill- Palmer Quarterly 39, 391-414.

Vasta, R. (1979). Studying Childre; An introduction to research methods San Francisco, C.A.: W.H. Freeman.

Viadero, D. (2003). R.I. District focuses on research-based Common Language. Education Week, 22, 29,120-121.

Wiles, J.W. \& Bondi, J.C. (2011). Curriculum development. A Guide to Practice $\left(8^{\text {th }}\right.$ ed). New Jersey Upper Saddle Rivers.

Williams, R. (2003). Higher order thinking skills. Challenging all students to achieve. Thousand Oaks, CA: Corwin. 
Archive: https://i-proclaim.my/journals/index.php/ajhal/issue/archive 